\title{
Contagions and Social Sustainability: Domains, Challenges and Sanitary Devices
}

\author{
Carlos Miguel Ferreira \\ ISCTE -University Institute of Lisbon, \\ Av. das Forças Armadas, Lisbon, Portugal; \\ Interdisciplinary Centre of Social Sciences -CICS; \\ Estoril Higher Institute for Tourism and Hotel Studies, Portugal

\section{Sandro Serpa} \\ Department of Sociology, \\ Faculty of Social and Human Sciences, \\ University of The Azores; \\ Interdisciplinary Centre of Social Sciences - CICS.UAc/CICS.NOVA.UAc; \\ Interdisciplinary Centre for Childhood and Adolescence - NICA -UAc, Portugal
}

\begin{abstract}
This article aims to understand the domains and conceptual uses of contagion, its modalities and its effects, in its different historical contexts and meanings, as an expression of the process of interdependence between the positions and the different points of view of different actors involved in multiple scientific, moral, social and political challenges. Another objective focuses on understanding the process of collective management of contagion, disease and health, where prevention is an essential element of its objectives and justifications, its discursive order, as well as its practical activities.
\end{abstract}

\section{Keywords}

Contagions, sanitary devices, public health, social sustainability.

\section{Introduction}

The domains and conceptual uses of contagion, its modalities and its effects, in its various historical contexts and meanings, express the interdependence between the positions and the different points of view of the various actors involved in multiple scientific, moral, social and political challenges.

The literal or metaphorical use of the notion of contagion, inherent in these relationships of interdependence between individuals and social structures in a given space-time, has several underlying assumptions. This notion can be mobilized to qualify the distribution of a medical and/or social phenomenon characterized by its modalities of expansion, transmission and distribution, by a speed of exponential propagation, sometimes associated with an unexpected origin and an unpredictable end. The notion of contagion often expresses fear, vulnerability, ignorance and powerlessness, but it also implies, in order to deal with these disruptive situations, the mobilization of warning procedures and prevention devices. The discourses on contagion configure the normative justifications, developed by the institutions to formulate and 
implement coercive measures, namely excommunication or quarantine. Naming contagion makes it possible to naturalise a threat, which an uncontrolled proliferation of an illness or disease poses in a particular community, justifying the adoption of measures to manage this threat (Coste, Minard \& Robert, 2011, p. 12).

The notion of contagion imbricate itself to the notion of contamination. Although these terms have a common Latin root (contagion = cum tactus, contamination = cum tangere) which refers back to contact and the sense of touch, their syntax differs. The phenomenon that these notions describe is always relational, the role attributed to the reports (elements or individuals placed in relation) may be different. To describe a contagious phenomenon is to say, simultaneously, that one individual contaminates another and that these individuals may only be transmitters of something they do not master. The notion of contamination has the role of specifying what happens to the reports (such an individual has been contaminated, such a person has contaminated another). In the process of contamination, causes and effects are taken into account with its agents and patients; the figure of contamination refers to a more impersonal, more diffuse, more involuntary process, in which the component of intentionality is more difficult to evaluate (Coste, Minard \& Robert, 2011, p. 12; Cala, 2011, p. 2-3). The notion of contagion, historically associated with diffuse reactions of fear, did not originally refer to something known, which presented a morphological structure such as a microbiological agent capable of producing diseases in the body. Non-specific and much broader than the concept of transmission, the term contagion remained united, until the 15th century, to the term contact, used with the sense of "the act of exercising the sense of touch". Transmission relates illness to contact and the sense of touch. Until the fifteenth century, the terms contagion and contact remained united, and were used with the sense of "act of tact" (Marques \& Ferreira, 2010; Nutton, 2000; Kuriyama, 2000; Pelling, 1993; Czeresnia, 1997). The dangerousness of the plague was not only associated with the proximity to the sick that infected the healthy, talking and caring for the sick, touching clothes or anything else that had been used or manipulated, transferred the disease to the healthy individual. The objects of the sick or the dead also contaminated and killed the animals in a short time (Czeresnia, 1997). From the 16th century onwards, the word contaminate - from late Latin contamare - became predominantly used in the sense of contagion, while the term contact maintains the same previous meaning (Cunha, 1982). From the 19th century onwards, contagion was defined as "transmission of disease from one individual to another". Since then, the term transmit - with the meaning of "to send; to send; to let pass beyond; to report" - has also been used in the sense of "transmissible", becoming synonymous with contagion (Cunha, 1982). For Czeresnia, the concept of transmission emerges with the displacement of the perceptual structure, just as the discourse about the spread of 
epidemics also shifts from the imprecise senses of smell and touch to the sense of vision (Czeresnia, 1997).

\section{Methodology}

The methodology followed in this article is of an intensive type. It is about understanding the multiplicity of facets and dimensions that characterize this polyhedral process of social configuration contagion.

Documentary analysis was the privileged technique in this research, developed from different types of documentary sources. In a documentary study, documents can be understood as "means of communication", elaborated with some purpose and for some purpose. They can be understood as a form of contextualization of information, being analyzed as communicative devices methodologically developed in the production of versions about events (Flick, 2005). Considering that documents are communication tools and media, which express objective forms of experience and knowledge related to a certain sector of human practices, it implies that the whole document can be contextualized in a certain social and cultural framework. In this framework marked by its complexity, the document enters the framework of social relations and assumes a certain role in the game of social relations by attributing value to certain acts or configuring certain relations (Lalanda-Gonçalves, 2014, p. 2).

The type of documentary sources privileged refers to medical and welfare journals, manuals, academic theses and articles produced in the medical field and in the field of social sciences, which by expressing different positions and interests in the medical, welfare, political and societal field were important to understand the construction of the discursive space on the social configuration contagion and the modalities of its medical and political management. These documents constitute and manifest the politics of cognition: language is used to construct an "official" reality often around classifications that produce the promotion or marginalization of ideas, and the current concepts, which selectively define situations, model the preferences, perceptions and cognition of readers. These documents can be considered as places of symbolic struggles for the perception of the social world. These symbolic struggles can take two different forms. The objective form shapes the possibility of acting through actions of representation, individual or collective, aimed at showing and promoting certain realities. The subjective form shapes the possibility of acting by trying to change the categories of perception and appreciation of the social world, the cognitive and evaluative structures: the categories of perception, the systems of classification, that is, the words, the names that build social reality as much as they express it (Carvalho, 2000; Ramos, 1981). 


\section{The Lexical Field of Contágio}

The lexical field of contagion (contamination, infection, epidemic...) is currently seen as being structured from the discourses produced in the medical field. The medical notion of contagion refers to the transmission of an illness from a patient to a healthy person. Transmission is essentially the transmission of a disease. In all transmission one must distinguish between an act and an agent. The agent is the one who carries out the transmission and the act is the transmission itself, considered as a function. In French the term contagion expresses contagionact and the term contage is used to express contagion-agent. In English, Spanish and Portuguese there is only the generic term contagion, contagion and contagion to express the function and the agent. Contagious diseases can be transmitted by touch, by direct contact between humans, without the need for an intervening vector or vehicle. A communicable (or infectious) disease is caused by the transmission of a specific pathogen to a susceptible host. Infectious agents can be transmitted to humans: directly, from other infected humans or animals, or indirectly through vectors (insects or animals that drive the infectious agent from person to person), airborne particles or other vehicles (contaminated objects or items such as clothes, cutlery, water, milk, food, blood, plasma, parenteral solutions or surgical instruments) (Bonita, Beaglehole \& Kjellström, 2006, p. 117). Although molecular biology has deeply complexed the original explanatory model, this model remains satisfactory: an organic agent passes from one individual to another producing in the second the disorders observed in the former (Paillard, 1998, p. 9). The "doxographic" discursive records produced on the medical notion of contagion express a mnemonic linearity, an intention to construct a narrative that emphasizes the uninterrupted continuity of the idea of contagion. Several medical historians consider that the genesis of the idea of contagion by the transmission of a pathogenic germ is associated with Girolamo Fracastor, who in his work De Contagione et Contagiosis Morbis et Curatione published in 1546, defended the contagious nature of Naples' evil, syphilis. Although the idea that invisible living elements, seminarians who penetrated the body through the pores or mouth at the time of inspiration or swallowing, were at the origin of contagious diseases, was defended by Fracastor, long before Terrentius Varron (116-27 B.C.) understood that minute animals were susceptible to transmitting diseases (Paillard, 1998, p. 10-11; Penso, 1981). For Patrice Bourdelais, until the beginning of the 19th century, there was no strict distinction between contamination, infection and contagion, despite Fracastor's work on syphilis contagion and his intuitive description of infravisible germs (Bourdelais, 1998, p. 22). These positions reveal the "proto-idea" of living and invisible pathogens that marked the "ways of seeing and doing" of agents inscribed in the bacteriological/microbiological thinking style. The "proto-ideas" embrace all the allusions of the 
past, able to make prior reference to everything that is adopted by the collective of thought and exert influence on the constitution of the networks of meanings created by the scientist, such as the concepts (Fleck, 1986).

However, it can be considered that the genesis and the primordial use of the notion of contagion did not have a medical origin and meaning and that the lexical appropriation movement operated in the opposite direction: from evil to disease. The idea of contagion develops with a strong moral connotation, which describes the possible spread of the disease more than the disease (Fossier, 2011, p. 24). In the West, until the 13th century, the topic of moral contagion developed in a theological context (contagion of sins, vices and heresies) without explicit reference to the contagionist model produced by medicine, even though diseases such as plague and leprosy were always associated with vices. In the Christian and Latin world the first uses of the terms contagium and contagium have emerged in doctrinal or normative texts, harshly condemning heretical groups. In the early theology of the first centuries of Christianity, the two terms were used to designate the transmission of original sin from generation to generation. These notions contributed decisively to configuring the medieval sphere of the sacred, which encompasses what was neither contaminated nor polluted by original sin. The notion of contagion became the reference for the disciplinary mechanism developed by the Church, which, faced with the spread of evil, oscillated between pastoral care, the institution of denunciation and the devices of exclusion (fines, excommunication, degradation, corporal punishment) (Fossier, 2011, p. 24).

This moral and metaphorical meaning of the contagion of heresies, of sins and later of crime and murder expresses a process of naturalisation and moralisation of social phenomena presented as potentially disruptive and difficult to control, implying the implementation of exceptional procedures. Priority was given to the articulation between sanitary prophylaxis measures and penal repression devices, the emergence of institutions of confinement and isolation (lazarets, hospitals, asylums, prisons), whose more or less closed character would allow the evil to be kept at a distance, but could instead, by promoting physical and moral promiscuity, aggravate its proliferation.

Paradoxically, the constitution of a medical theory of contagion opened, during the 19th century, a space of legitimization to the theories of contagion applied to crowds, crimes, prison or literature. The notion of "moral contagion" was relevant to the elucidation of collective possession by the "sciences of the psychism". The constitution of criminal science as a specific disciplinary space developed, in addition to the definition of the psychological profile and typological classification of dangerous individuals, from the initiative of doctors concerned with the amoral dimension of crime, aiming to establish an epidemiology of crime aimed at 
preventing its contagious character (enhanced by imitation of facts transmitted by the press). The threat of moral contagion was also invoked to prohibit the reading of works considered dangerous. In 1818, a Portuguese royal censor wrote in one of his opinions:

"There are, however, in the French language, ungodly, seditious, inflammatory books, and of an execrable obscenity, directly composed and destined to shake and subvert the throne, the altar and the good customs. It is against these, in particular, that censorial severity must be exercised, and more austere and vigorous measures must be taken than against the plague, whose damage seems to me to be much less than that of modern mental and moral contagion" (Neves \& Ferreira, 1989, p. 115).

Certain moral values are protected and certain social rules are defined by beliefs in dangerous contagion and the ideal order of society is maintained thanks to the dangers that threaten transgressors (Douglas, 1991).

The idea of contagion without bodily contact, whether indirect or via a vector, is present in numerous theories of contagion in different societies. The transmission of evil may not be associated with a simple material contagion, and disease (whether transmitted by air or by the proximity of the other's body) can always be viewed as a tangible trait of an impurity, of a world symbolic of impurity, induced by the social bond that unites the individual, classified as contaminated and contaminating, to others and inherent in the demarcation of borders between order and social disorder (Douglas, 1991; Cruz, 2007/2008). This symbolic dimension of impurity may shape cognitive evaluations of non-contagious diseases - from a medical point of view - and may assume a contagious character in the perceptions and representations expressed by sick individuals and others, where contacts may be considered dangerous and affect those closest to the patient. Contrary to biomedical conceptions, which circumscribe contagion to the biological and physiological sphere, clinically attested, patients suppose that a certain disease, namely alcoholism, although not transmitted, can be contagious, affecting, above all, those who are closest to the "alcoholic", that is, their relatives, friends and their work environment. The model of contagion present in the representations formulated by various patients differs from the idea of direct contamination. In other words, it does not suggest that the relatives and friends of the "alcoholic" individual start drinking like the patient, but rather that they are affected by the illness of the drinker. Alcohol, understood as the bearer of impurity, also "contaminates" the places where it is consumed. That is why the alcoholism recovery program is also called by the members of the associations "former alcoholics" as an "avoidance program", in which the patient must avoid "old habits", "old friends" and "old places" that he used to frequent in the times of active alcoholism (Fainzang, 1994). 
The belief in the contagion of non-contagious diseases and of events perceived as dangerous can be identified with the symbolic dimension of impurity that expresses the dangers incurred by the social order and the purity of a group, appearing as a guarantee of the avoidance of any physical and social approach to the sick and other individuals perceived as dangerous in a given community. This articulation between impurity, purification and interdiction of contact by believing in contagion configures the symbolic management of internal and external dangers that threaten the various societies in different time-spaces. The theme of impurity and its purification by the removal of socially dangerous elements was present in Greek antiquity as a principle of social regulation; it persists in the Indian caste society; in the 19th century, in Europe, the dangers of a sexual freedom associated with the belief in syphilis developed an obsession with contagion. Recently, the AIDS epidemic has revived this fear, several arguments have been supported by parties of the extreme right who advocated, against the risks of contagion from AIDS, measures of exclusion of the sick; equally drastic as those that related to another social danger: immigrants (Hass \& Jodelet, 2007, p. 127-128).

The perceptions and representations of contagion convey negative or derogatory cognitive sensations and evaluations suggesting the malignity of the other, the other as a source of threat and danger, arousing a generic fear in which contact is perceived as a possibility of aggression and contamination. The notion of contagion is related to experiences of fear, exasperation, denial and rejection of the other, recalling the old attitudes of populations threatened by the plague such as those of escape, purification and isolation (Bourdelais, 1989). The images associated with the notion of contagion in the case of the HIV/AIDS epidemic gave rise to social, economic and political reactions of such breadth and scope that they were called the "third epidemic" or "epidemic of the year 2000" (Czeresnia, 1997; Fabre, 1993) - one that produced social repercussions of panic, ignorance and stigmatization of the sick and the social groups most affected. The evidence of the "contagiousness" of AIDS was accentuated by its association with transgression and death. The notion of contagion was related to the linking of senses of sin, punishment and guilt to forms of transmission of the disease through sex and drug use (Czeresnia, 1997, p. 98). The medical-preventive discourse operates in relation to AIDS a dissociation between transmissible disease and contagious disease. HIV infection is classified as a communicable disease without conferring a contagious character. The notion of transmission, by defining the specific forms in which the etiological agent of the disease passes from one individual to another, builds a rationality capable of breaking with the fear associated with the classic notion of contagion. However, this rationality, made possible by the concept of transmission, is historically dated, which is linked to both the emergence of medicine and the modern concept of disease. The notion of transmission guides the formulation of a preventive 
discourse, as well as the constitution of norms and laws that aim to define rights, duties and arguments in opposition to hostile and irrational attitudes against the sick and social groups most affected (Czeresnia, 1997; Fabre, 1993).

AIDS was declared an epidemic, today the coronavirus (Covid-19) is seen as a pandemic, the new "plague". This "metaphoric virulence" is already present in its essence. We speak of "semantic contagiousness" because nosos in this type of contagion is the meaning. The "plague" is mainly "transmitted" in discourses, through the senses of death-contagion-evil. In various discursive records of a religious, poetic and medical nature, the term pestis and its derivations designate a terrible evil, a great misfortune, or even a polluted, contaminated, unhealthy, insane and often mortal condition. Contagious disease, but above all the great evil.

\section{Collective Management of the Contágio}

In the collective management of contagion, disease and health, prevention is an essential element of its objectives and justifications, of its discursive order, as well as of its practical activities. Prevention can be considered as declining in different forms that can be grouped in four schemes: The magical-religious model, which inscribes the interdicts and obligations in a sacred register in order to avoid or to turn back misfortune, through divinatory and propitiatory rituals; a model of profane constraint, which falls within the political space and proceeds by social control, whose paradigmatic form is the health cordon; Pasteurian model, which, based on science and technology, is resolutely based on the terrain of effectiveness, illustrated by the historical successes of vaccination; contractual model, which supposes the acquisition of a partenarial agreement and in which health education would be the central figure. Reading these models according to a chronological progression, in which each one of them is isolated, could make us believe in their linear succession. On the contrary, we are witnessing a sedimentation of these four schemes and, in contemporary societies, whether close or distant, tensions crystallize between the forms of beliefs and power they represent. Today, prevention is presented as a variable configuration of the four models (Dozon \& Fassin, 2001, p. 15-16).

In traditional societies, the collective management of adversity and disease is an undifferentiated activity. This relative indifferentiation manifests itself at two levels. On the one hand, the representations and practices mobilised do not constitute a clearly circumscribed set. Both disease and death fall into the category of misfortune, which also includes other adverse events such as the loss of a harvest or the bad result of a hunt, drought, floods, hunger; epidemics are thus part of a broader category of misfortune facing societies. It is generally the same divinization and conjuration procedures that are used, the same soothsayers and oracles that are consulted, the same types of interpretation that are advanced. On the other hand, 
prevention presents itself as a set of beliefs and rites that touch all social activities rather than a set of knowledge relating to the disease. In these societies, prevention, that is, the set of beliefs and acts by which individuals protect themselves from illness and misfortune, appears as the central figure in the collective management of the disease. Prevention is based on the magicalreligious model, which inscribes the interdicts and obligations in a sacred register in order to avoid or reverse the misfortune. This model corresponds to the set of prohibitions and obligations, individual or collective prescriptions and proscriptions, divinatory practices and propitiatory rites often accompanied by sacrificial rites and the making of protective objects (Dozon, 2001, p. 29). The collective management of disease and adversity is not the responsibility of specific institutions (Fassin, 1996, p. 216-217).

The growing social differentiation - social division of labour, the process of urbanisation and industrialisation, and the consolidation of functional and professional hierarchies - has required the creation of new forms of functional regulation and coordination between social structures and individuals, also present in the collective management of the disease. The greater the differentiation, the greater the need for institutional organisation that ensures the domination, integration and interdependence of individuals (Mozzicafreddo, 1998, p. 259-260). The historical processes of urbanisation and industrialisation, which led to the construction of an urban and industrial society, have provoked a continuous growth of human interdependence, in its social and spatial dimensions. The conditions of deprivation and destitution of each social group affected others, making it practically impossible for economic, political and social elites to escape the effects of the precarious living conditions of the poor and destitute population and the diseases they spread (Swaan, 1988).

Epidemics can be considered paradigms of interdependence, expressing the "public evil" that hits all of society, dominant and dominated. Awareness of interdependence does not guarantee the development of collective action. Epidemic diseases generated fear and distrust between rich and poor. The possident classes blamed the poor for the disease. The working classes blamed the rich for creating these diseases to eradicate the poor. The public authorities established various provisions to impose medical discipline and to force the rich and poor to accept the guidelines of public hygiene. These measures involved compulsory cooperation at various scales, including local and national, between these social categories. State policies were the unforeseen historical result of a process of adopting measures to deal with precariousness and social destitution. Initially, these problems would have been addressed with individual and voluntary solutions. As their scale and complexity increased, collective but still voluntary forms of combating destitution and social deprivation developed. These forms, mainly related to voluntary institutional charity, found limits of scale, coordination and collective action, 
especially with the continued growth of social problems to be faced, as well as links of interdependence. This process led to the nationalization of actions against need, which were then collective, compulsory and centrally coordinated (Swaan, 1988; Konstantinos, 1997).

Preventive administrative and health structures coordinated by the central government, although initially temporary, have emerged in the process of collective management of epidemics, including health councils, health cordons, quarantines and lazarets. The dominant position occupied by political actors in relation to doctors and the increasing extension of their prerogatives in the various areas of social life were noted. As regards endemic diseases, their collective management has been guided by the development of continuous collective actions, because these diseases are linked to permanent problems affecting a population. These diseases, socially defined as "social scourge", to which the problems of morbidity and mortality are inherent as permanent phenomena of a "population biopolitics" (Foucault, 1976) emerging throughout the 18th century, express the institutionalisation of concerns, on a permanent basis, for the health of the population by the State, and not only occasionally as until then the public authorities faced epidemics. The genesis of the concerns, in a permanent way, for the health of the populations by the State is related to a process that presents two interdependent levels (Pinnel, 1998). The first is characterised by the increasing attention given to health, the body and medicine in the courts. The life of the court opens a space for the expression of a new sensitivity to the morbid manifestations of the body, which is translated into a search by medicine and doctors and the enthusiasm of courtiers and the urban bourgeoisie for a "profane" medical literature vulgarizing a practical knowledge of the pharmacopoeia. The second level of transformation is in relation to the process of building the state as a relatively autonomous field, which exerts a power of centralisation of physical force and symbolic force and is indissociably accompanied by the construction of the unified social space that falls within its competence (Bourdieu, 2014, p. 185; Pinnel, 1998). The constitution of a public administration is imbued with the progressive imposition of a triple royal monopoly: symbolic monopoly, fiscal monopoly and monopoly of legitimate violence, which characterises the emergence of the state (Bourdieu, 2014; Elias, 1983). The challenges posed to the public administration in assessing the wealth of the kingdom have gradually brought out the notion of population, that is, a representation of all individuals who live in a given territory and who, through their work, produce wealth in different forms. The investment of political actors in the collective management of the disease has made it possible for the autonomous area of public health to emerge. Politicians can be considered to be power relations mobilized in the public space for the control of decisions and actions that have as their object assets considered as collective (Fassin, 1996). In this way, the collective management of disease and health can be designated as public health from the moment it 
enters the political domain, or more precisely, when it is part of a conception and institutionalisation of the politician where the government of life finds its place (Fassin, 1996). Thus, it is with the strengthening of centralised political institutions, within the framework of the constitution of modern Western states, that the collective management of disease and health, as public health, enters into the practice of government, and is therefore inseparable from the figure of the state (Fassin, 1996). The state, as the political configuration of society as a whole, in the formulation of Norbert Elias, not only structures the relations between society and political authority, but also, and above all, the relations within society itself, namely the influence it exerts on the structure and collective action (Mozzicafredo, 1998, p. 253). But if the establishment of a sanitary order is part of the conditions of the construction of states, the understanding of the transformations of the state structures inherent to the collective management of health is fundamental for the analysis of the process of collective management of disease and health. Although the various European States were concerned about the health situation of their populations, this did not mean that collective health management should adopt the same modalities and outlines everywhere. On the contrary, the history of public health reveals how much health order reflects the particular social and political structures in each place and in each era (Fassin, 1996).

Epidemics can be seen both as revealing the interaction between the medical and political worlds and as catalysing the dynamics of collective disease management.

The collective management of the Black Plague, and the recurrent epidemic outbreaks, took the form of a set of specific procedures and institutions: health councils, health cordons, quarantines, and lazarets, which presented themselves as the first preventive administrative and health structures, coordinated by the central government, although initially of a provisional nature, which first developed in the States of Northern Italy in the 14th and 15th centuries and then spread to the various European States in the following centuries. These devices to combat the epidemic express the dominant position held by political players in relation to doctors. The power of decision remains in the hands of the nobles who administer the health councils.

A set of sanitary procedures against the plague was institutionalized from the 14th and 15th centuries: the control of travelers, vagabonds, beggars and city dwellers; the institution of quarantine; the houses abroad, but fundamentally the lazarets. The institution of quarantine, which allowed control by isolating people and goods affected or suspected for a specific period and under strict conditions - until it was established that they were not affected by the plague. The sanitary cordons were a sanitary mechanism mobilised to prevent the proliferation of epidemics, consisting of one or several concentric lines of defence around the site to be protected. This device could be accompanied by land lazarets. The extramural houses, but 
fundamentally the lazarets to isolate the suspicious or infected patients to "be treated or die outside the city". The emergence of these disciplinary devices was thus the realization of the "political dream of the plague" of ordering disorder. The essential fact became the institutionalisation of public health by the State, i.e. the establishment of an administrative mechanism whose purpose was the collective management of a disease, its surveillance and its prevention.

The quarantine system and the lazarets were based on a logic of exclusion and purification of persons classified as the "other", of goods and places considered unhealthy or affected by pestilence. The time gap that existed between the contraction of the disease and its development was also a reason for fear. The apparent state of health of the contagion carrier was another of the dilemmas that those in charge of public health had to deal with and who conformed to quarantine as an institution that was not intended to combat the disease itself, but to counteract the possibility of the plague appearing. The defence procedures, although based on total exclusion of communications - prevention - tried to develop a filter that did not completely interrupt communications, were based on the categorisation of the suspect in the light of the patient's evidence. The time factor in quarantine played a very relevant role: the finding of an incubation time of the disease in the carrier of the contagious disease during which the appearance is healthy justified the construction of a system based on disease prevention (Tolós, 2006).

The old lazareto and the new lazareto originated in Venice in 1373 and 1418 respectively, both were spaces of isolation and defense. If the former remained a place of pity, the place of assistance provided by charitable hermits, experts in the care of "lepers", the latter was a place of control where the procedures for admission and distribution in use in the hospital were in certain respects; the quarantine of suspected cases and the sending to the old lazareto of those who were considered contaminated (Cosmacini, 1992). In general, a distinction was made between "infected" and "suspected". An "infected" was one whose contagious disease had been diagnosed by a doctor or surgeon. In compensation, "suspects" were all those who had come into contact with an affected person or objects considered to be infected, as well as all those who came from a supposedly pestilent space (Cipolla, 1976).

The lazareto was an enclosed space devoid of ambiguity. A space of hospital structure, outside the city, but not opposed to it. A space created for a temporary, transitory period; a space that is not simply enclosed, but completely barricaded. A space of segregation for extremely contagious and extremely dangerous individuals, even if the patients are not necessarily irrecoverable, even if the virulence of evil rarely left room for a possibility of cure (Cosmacini, 1992). Lazareto was a sanitary establishment based on a prison logic. This confinement was a 
collective act - since it acted on passengers, goods and ships in transit, even when the nature of their health licence exempted them from quarantine. The core of the institution was the suspicion that was continually on everyone and that at any given time an exemplary will could impose quarantine on the boat least susceptible to contagion. The logic of quarantine was based on the secrecy of the operations that took place in the lazareto expressing the absolute power of the authorities of this sanitary establishment, in order to avoid all physical communication and compartmentalise spaces suitable for individuals and goods, but also to enable the control of information. Another relevant element was the exemplary status of the penalties for noncompliance with quarantine regulations and for any suspect who arrived at the port. The lazareto authorities could impose long quarantine, burn cargo, block the docking of ships from infected areas and there was, in many of their interventions, an exemplary intent (Tolós, 2006; Bonastra, 2010).

\section{Conclusion}

The representations about epidemics and contagions are still shaped today by Thucydides' gaze. For Thucydides, the "plague" in Athens was not only a health crisis, it was also a great moral crisis. Nosos, that is, "sickness," infection not only destroys the body; nosos, that is, "dementia," also destroys, even momentarily, a society, institutions, customs. An epidemic is not only the devastation and suffering caused by the spread of infection, it is also the brutal disorganization that follows, the weakening of the state, the disintegration of authorities, social structures and mentalities. Thucydides speaks of anomy, that is, of wickedness and lawlessness, of humanity without law or rule (Zylberman, 2012).

Epidemics and contagion have various effects on societies, including on beliefs, institutions, social, demographic, economic and political structures. Epidemics and contagion reinforce prejudices and enhance stigmatization processes: against the Jews (plague 1347-1350), against the poor in the Renaissance (plague, typhus), against Irish immigrants in the 19th century (cholera), against the poor in the 19th and 20th centuries (tuberculosis), against the four Hs (homosexuals), Haitians, haemophiliacs, heroinomaniacs) in the 1980s (HIV/AIDS), against Africans (Ebola), against Chinese and Asians (bird flu, SARS, coronavirus), against the "stranger", the "foreigner": the "other"...

The history of medicine attests to the reconfiguration of the etiology of epidemics and contagions, but the interpretation of the evil reported first to the "tragic sky", then to foreign communities or those considered dangerous, generates a whole set of beliefs, fears and eschatological representations. What relates very different epidemics at the etiological level is that they have stigmatized affected individuals, groups and communities, as well as having been 
strongly incorporated, both in erudite discursive records and in collective memory and imagery. The old regime of evil: guilty man, vengeful God, evil world, tends to be replaced by a new regime of evil: uncontrolled body/individual, weakened power, dangerous world in which individual interactions and social relations in their various scales produce and enhance "Nosos".

The epidemic, as a health crisis, is imbued with the anomaly, the expression of a political-moral crisis. The health crisis is an epidemiological, medical crisis, but also a political crisis and a crisis of governance. Clinical and epidemiological approaches are imbricated with a political component (power, violence, constraint) and a governance component (state structure, behaviour of governments). The state's dominance over health crises depends on its capacity to create, develop and manage complex and specialised organisations (care and health system, agencies, committees of experts), its capacity to ensure the continuity of its functioning and the mobilisation of its resources, its power to control the use of coercion in response to health crises. The crisis is not something that will be, or will be: it is something that comes, the pandemic that comes' (Zylberman, 2012, pp. 48-50).

\section{References}

Bonastra Tolós, J. (2006). Science, society and territorial planning in the institution of the Lazaretto, Doctoral Thesis, University of Barcelona. Department of Human Geography

Bonastra, Q. (2010). Sanitary enclosures and control spaces. A morphological study of quarantine architecture. Dynamis, 30, 2010

Bonita, R., Beaglehole, R. \& Kjellström, T. (2006). Basic Epidemiology. World Health Organization. Bourdelais, P. (1989). Contagions d'hier et d'aujourd'hui. Social Sciences and Health, VII (1), fevereiro, 1989.

Bourdelais, P. (1998). "La Construction de la Notion de Contagion: Entre Médecine et Société", in Communications, La Contagion, n. 066, p. 22.

Bourdieu, Fr. (2014). About the State. Course at the Collège de France (1989-1992). Lisbon: Editions 70.

Cala, G. (2011). "Call: Contagion/Contamination. Calls for Contributions/Traces. Revue de Sciences Humaines, 21, http://traces.hypotheses.org/61

Carvalho, L. M. (2000) "Nós Através da Escrita: Revistas, Especialistas e Conhecimento Pedagógico (1920-1936)", Cadernos Prestige, n.ㅇ 3, Lisbon: Educa

Cipolla, C. M. (1976). Cristofano e la Peste, Bologna, II Mulino, 1976

Cosmacini, G. (1992). Healing and Reforming. Medicine and Health in Italy from the Great Plague to the First World War. Paris: Éditions Payot.

Coste, F. Minard, A. \& Robert, A. (2011). "Contagions. Histoires de la Précarité Humaine" Tracings. Revue de Sciences Humaines [online], 21 . URL:http://traces.revues.org/5126, 
Cruz, A. (2007/2008). "The mask behind the veil of stigma: does the thought of Lévi-Strauss fit into a reflection on the leprosy experience? Anthropologia Portuguesa, 24/25, Coimbra, Departamento de Antropologia da Universidade de Coimbra.

Cunha, A. G. (1982). Dicionário Etimológico da Língua Portuguesa, Rio de Janeiro: Nova Fronteira.

Czeresnia, D. (1997). From Contágio to Transmission: Science and Culture in the Genesis of Epidemiological Knowledge [online]. Rio de Janeiro: Editora Fiocruz.

Douglas, M. (1991). Purity and Danger, Lisbon: Editions 70.

Dozon, J.P. \& Fassin, D. (2001). "L'universalisme bien tempéré de la santé publique" (Introduction), in Jean-Pierre Dozon, Didier Fassin (Dir.), Critique de la Santé Publique. Une Approche Anthropologique, Paris: Éditions Balland.

Dozon, J.P. (2001). "Quatre modèles de prévention" in Jean-Pierre Dozon, Didier Fassin (Dir.), Critique de la Santé Publique. Une Approche Anthropologique, Paris: Éditions Balland.

Elias, N. (1983). O Processo Civilizacional, II Vol., Lisbon: Edições D. Quixote.

Fabre, G. (1993). La notion de contagion au regard du sida, ou comment interfèrent logiques sociales et catégories médicales. Social sciences and health. Volume $11, \mathrm{n}^{\circ} 1$.

Fainzang, S. (1994). Alcoholism, a contagious disease. Anthropological reflections on the idea of contagion. Revue Ethnologie Française, vol. XXIV, n.o 4.

Fassin, D. (1996). L'Espace Politique de la Santé. Paris: PUF.

Ferreira, C. M. (2020). Making the Time: Sanatorium and Medicalization. Porto: Creative Strategies

Fleck, L. (1986). The genesis and development of a scientific fact. Madrid: Alianza Editorial

Flick, U. (2005). Métodos Qualitativos na Investigação Científica, Lisboa: Edições Monitor.

Fossier, A. (2011). "The contagion of sins (11th - 13th century). Aux origines canononiques du biopouvoir", Tracés. Revue de Sciences Humaines [.online], 21. URL:http://traces.revues.org/5126

Giuseppe, G. (1981). Penso, The Conquest of the Invisible World. Parasites et Microbes à Travers les Siècles, Paris: Éditions Roger Dacosta.

Hass, V. \& Jodelet, D. (2007). "Pensée et mémoire sociales",in J. P. Pétard (Coord.), Psychologie Sociale, Rosny: Éditions Bréal.

Konstantinos, C. (1997). Sous l'aile protectrice de l'État (Abram de Swaan, translated from English by L. Bury), In Flux, n²7-28.

Kuriyama, S. (2000). Epidemics, Weather, And Contagion In Traditional Chinese Medicine. In L.Conrad Li, Wujastyk, D (Eds): Contagion. Perspectives From Pre-Modern Societies. Aldrshot, Ashgate, pp. 3-22;

Marques, M. S. \& Ferreira, C. M. (2010). Contágio: Contribuição para a Epistemologia e a Ética da Saúde Pública. Acta Médica Portuguesa, 23, 533-556; 
Mozzicafreddo, J. (1998). "State, Modernity and Citizenship", in José Manuel Leite Viegas and António Firmino da Costa (org.), Portugal que Modernidade? Oeiras: Celta Editora.

Neves, L \& Ferreira, T. (1989). "The fear of "abominable French principles": the censorship of books at the beginning of the 19th century in Brazil", Acervo, Rio de Janeiro, v.4, n. 1

Nutton, V. (2000). Did the Greeks have a word for it? Contagion and Contagion Theory in Anciente Antiquity, in L. Conrad, D. Wujastyk (Eds): Contagion. Perspectives from Pre-modern Societies. Aldrshot: Ashgate. pp. 137-162;

Paillard, B. (1998). "Petit historique de la contagion, Communications, 66, La Contagion, Paris: Éditions du Seuil.

Pelling, M. (1993). Contagion/Germ Theory/Specificicity. In W. Bynun \& R. Porter (Eds.) Companion Encyclopedia Of The History Of Medicine. London: Routledge, pp.309-334

Pinnel, P. (1998). "Médicalisation et procès de civilisation" in Pierre Aïach, Daniel Delanoë (Dir.) L'ère de la medicalisation. Ecce homo sanitas. Paris: Anthropos.

Ramos, A. G. (1981). The New Science of Organizations, Toronto, University of Toronto Press.

Rolando Lalanda-Gonçalves, R. (2014). "O documento nas ciências sociais: construção e contextos sociais" in As transformations do documento no espaço-te tempo do conhecimento / Les transformations du document dans l'espace-temps de la connaissance. III International Colloquium of the MUSSI Network / III Colloque International du Réseau MUSSI, 10-12 nov. 2014

Swaan, A. (1988). In Care of the State. Health Care, Education and Welfare in Europe and the USA in the Modern Era. Cambridge: Polity Press.

Zylberman, P. (2012). "Health crises, political crises", Health Forums, 1 (No. 34). 